equipment for use in the development of the Colonies.

At the conclusion of the meeting the following resolutions were proposed and carried unanimously :

(1) That this Joint Meeting of the Geological Society of London and of the Institution of Mining and Metallurgy welcomes the attention now being given to the resources of the Colonial Empire and desires to stress the importance of Geological Surveys in the well-being of the Colonies, especially for the development of mineral resources and in connexion with water supply, public works, soil conservation, agriculture and forestry.

(2) That this Meeting views with concern the progressive deterioration of status of certain Colonial Geological Surveys and the discouraging conditions under which these Surveys are now functioning. It is also of opinion that Colonial Government Departments do not fully appreciate the practical value of geology to the community and the need for maintaining the individuality of the Surveys, under the direction of competent and experienced geologists.

(3) That this Meeting advocates : (a) the appointment by the Colonial Office of a Colonial Geological Surveys Advisory Board, (b) the appointment to the staff of the Colonial Office in London of a scientific Director-General of Colonial Geological Surveys, who should report periodically to the Advisory Board and should inspect the work of the Colonial Geological Surveys from time to time.

(4) That this Meeting urges that the deputation appointed by the Councils of the Geological Society and the Institution of Mining and Metallurgy jointly should wait upon the Secretary of State for the Colonies and submit their views with the object of increasing the scope and fostering the welfare of the Colonial Geological Surveys as an essential part of the post-war development programme for the Colonial Empire.

We are informed that the proposed deputation has since been favourably received by the Secretary of State for the Colonies.

While it seems clear that the action taken was well justified, in fairness to the Colonial Office it should be stated that a certain amount of attention has recently been given to the matter. Following on the passing, in 1940, of the Colonial Development and Welfare Act, a Colonial Research Committee was appointed, in June 1942, to advise upon the expenditure of the annual sum of $£ 500,000$ provided by the Act of 1940 as provision for Colonial research, and to assist in co-ordinating the whcle range of research in Colonial studies. This Committee recently published its first progress report (see NaTuRE, 153, 119 ; 1944). In this report it is pointed out that Geological Surveys would come within the Committee's purview, and it is also noted that they do not at present exist in certain Colonies. The Committee further directs attention to the fact that mineral development of Colonies is impossible without accurate topographical surveys. A grant of $£ 7,000$ to enable the Geological Survey of British Guiana to be carried on on a proper basis is recorded in this report; and, according to The Times of December 31, 1943, a further grant of $£ 32,000$ has been made for geological survey work in Nigeria.

The timely aetion taken by the Geologieal Society and the Institution of Mining and Metallurgy will, no doubt, serve a useful purp se in impressing on the Committee the urgent need for further action in this direction.

\section{CANCER RESEARCH IN BRITAIN DURING 1942-1943}

THE twentieth annual report of the British Empire Cancer Campaign was presented recently at a meeting in London. In proposing the adoption of the report, Prof. E. C. Dodds dealt in a general way with the difficulties of presenting the results of scientific research on cancer to the public, and with the complexity of modern experimental biology. $\mathrm{He}$ made particular reference to the success obtained in the treatment of cancer of the prostate with synthetic œstrogens.

\section{Clinical}

Recently American clinicians have obtained good results in the treatment of cancer of the prostate with cestrogenic substances. Similar results have now been seen in Great Britain. In one case treated at the Middlesex Hospital, the results of the American observers have been completely confirmed in the twelve months that the patient has been under treatment. Seven cases have been treated with diethyl stilbœstrol at the Royal Cancer Hospital by Dr. J. Watkinson, in collaboration with members of the honorary staff. In five of these cases there was evidence of secondary deposits in bone and an increase in the acid phosphatase in the blood serum. In these five cases the treatment produced some regression of the primary growth, a fall in the serum acid phosphatase and a reduction in the pain due to metastases. In one patient regression of a lymph node deposit was observed. Two cases appeared to derive no benefit from the treatment, but on the whole the work is most promising.

The Clinical Cancer Research Committee gives an analysis of details of more than a thousand cases of intrathoracic cancer. The analysis in general is in agreement with existing knowledge. The incidence is high among painters, decorators, engineers and mechanics. It is low among clerks and typists. Although 74 per cent of the patients consulted a doctor within three months of the onset of symptoms, 90 per cent died within a year of the time when diagnosis was made.

Experience gained with the million-volt X-ray installation at St. Bartholomew's Hospital indicates that high-voltage therapy is particularly effective in the treatment of cancer of the rectum.

\section{Carcinogenic Agents}

Workers at the Royal Cancer Hospital have found that $1: 2^{\prime}$-diamino $1^{\prime}: 2$-dinaphthyl, which inhibits growth but has not produced tumours at the site of injection or application, induces multiple adenomas of the lung in mice. The substance thus has a remote carcinogenic action. Russian and French workers have obtained tumours in mice remote from the site of injection of extracts of human lung and liver. Many tumours have occurred at the site of injection of extracts of human organs, but such tumours have generally appeared at least twelve months after the beginning of treatment. The agents present in human organs appear to be weak and slow in action. As yet it has been irmpossible to ascertain before test whether a particular organ will give a carcinogenic extract, so that progress in this field has been slow.

Prof. H. N. Green and Dr. F. Bielschowsky have made further studies on the action of the carcinogenic insecticide, 2-acetylaminefluorene. When fed to malo rats, this substance produces tumours of the liver 
similar to those produced by 'butter yellow'. In female rats, it produces adenocarcinomas of the breast, although the substance itself does not appear to be cestrogenic. No other insecticides or phenothiazine derivatives have been found to have carcinogenic activity, but phenothiazone is toxic when fed in small amounte over a long period.

3 : 4-Benzpyrene was first isolated from coal tar ten years ago. Dr. I. Berenblum and Dr. R. Schoental, of Oxford, have recently investigated the carcinogenicity of fractions of coal tar separated by chromatographic methods. They find that the fraction containing the benzpyrene is less active than certain other fractions in producing cancer on the skin of mice and rabbits. American workers during the past year have published results showing that although benzpyrene is rapid in its action, the dose required to induce tumours in mice is much larger than the corresponding dose of $1: 2: 5: 6$-dibenzanthracene (W. R. Bryan and M. B. Shimkin, J. Nat. Cancer Inst., $3,503 ; 1943)$. In attempts to obtain new types of tumours in fowls at the Glasgow Royal Cancer Hospital, injections of benzpyrene and methylcholanthrene have failed to produce tumours. On the other hand, many tumours have been induced in chickens with dibenzanthracene. Experiments carried out at Sheffield suggest that cats are resistant to the action of benzpyrene and methylcholanthrene.

Dr. J. W. Orr has applied methylcholanthrene to the nostrils of mice from a strain (I.F.S.) in which breast tumours do not normally occur. No lung tumours were found, but of twenty-nine female mice treated in this way eighteen developed mammary cancer.

\section{Metabolism of Carcinogenic Hydrocarbons}

Dr. I. Berenblum and Dr. R. Schoental, working at Oxford, have found that benzpyrene is converted into 8-hydroxybenzpyrene, and that $1: 2$-benzanthracene is converted into 4 hydroxy $1: 2$-benzanthracene in the intestinal tracts of mice and rats. These phenolic substances which are formed are not carcinogenic. The Oxford workers have collaborated with scientific workers of the Royal Cancer Hospital in studying the growth-inhibiting power of these metabolism products and their derivatives. The metabolism products themselves have no growth. inhibiting activity, although some hydroxy derivatives, such as 4 hydroxybenzpyrene, are active growth-inhibitors. Some methyl derivatives of the metabolism products can inhibit the growth of tumours. The active substances of this type are all monomethoxy compounds, such as 4'methoxy 1 : 2-benzanthracene and 8-methoxy benzpyrene. The dimethoxy derivatives of carcinogenic hydrocarbons appear to be devoid of growth-inhibiting activity.

\section{Bone Tumours in Mice}

Some years ago Mr. F. C. Pybus and Dr. E. W. Miller of Newcastle-upon-Tyne developed a strain of mice in which bone tumours including sarcomas frequently occurred. In 1936, about one quarter of the mice which died had palpable osteomata or sarcomata, but since then the incidence of bone tumours has declined although the mice have been inbred. Over a ten-year period 21 per cent of females and 7 per cent of males of this strain died with bone tumours. The difference in incidence in the sexes suggests that costrone might have some influence on the development of these tumours. Dr. J. W. Orr has studied the effect of estrone on the histology of tho bones of mice. The bones of female mice of this 'Newcastle bone tumour' strain are unusual in that there is a considerable amount of medullary bone and a mosaic appearance in the cortex. The bones of spayed females of this strain resemble those of normal mice. Treatment of mice of other strains with cestrone causes osteoclastic changes, including both resorption and production of bone. The mice of the Newcastle bone tumour strain are exceptionally susceptible to the action of cestrone. A sex hormone, in addition to other unknown factors, probably plays some part in causing the bone tumours that are found in this special strain of mice.

\section{Filterable Agents}

Experiments carried out at the Middlesex Hospital show that injection of either proflavine or 5-aminoacridine into the breast tissue will localize the Rous sarcoma virus. The localization of the virus leads to the formation of a tumour at the site of injection of the acridines. Kieselguhr is a localizing agent, but is much less effective than the acridine compounds. Methylcholanthrene is a very feeble localizing agent. The effect is probably governed by the type of tissue reaction resulting from the injection. The acridine compounds have a mild toxic action and cause proliferation of muscle nuclei.

Only a few of the topics dealt with in the report have been mentioned, but it is clear that progress has been made in the face of difficulties and many new facts have been brought to light during the year under review. With its coming of age, the British Empire Cancer Campaign is to be thanked for the way it has raised funds to support cancer research and for the care with which it has organized and correlated the efforts of many scientific men working in fields directly and indirectly bearing on the subject.

E. Boyland.

\section{GYROSCOPIC PRINCIPLES AND APPLICATIONS}

YYROSCOPY, since it belongs to classical $\checkmark$ mechanics, tends to be neglected by the modern physicist. We have now to depend on the engineers and applied physicists to maintain the teaching of the subject. Its applications cannot be ignored; in the development of modern applied science we find many extremely important applications of gyroscopes; and in the increased use of bodies rotating at angular speeds that are being continually increased from year to year, we find gyroscopic effects that must be taken into account in the design of the supporting structure whenever the rotating bcdy, whether it be engine, wheel or pro. peller, has the direction of its axis of spin altered. When a motor-car turns to the left, the spin of the engine causes a transfer of load from rear axle to front axle, and the spin of the wheels gives a transfer of load from inner to outer wheels. When a singleengined aeroplane turns to the left, the nose tends to dip; when the turn is to the right, the gyroscopic effect tends to raise the nose. When a twin-engined plane, with propellers turning in opposite directions, alters course, the leading edge of one wing tends to dip and the leading edge of the other tends to rise, so that additional stresses on the structure are intro- 